\title{
Practicing various sports disciplines and their impact on the occurrence of hallux valgus
}

\author{
Uprawianie różnych dyscyplin sportowych \\ a ich wplyw na występowanie palucha koślawego
}

\begin{abstract}
The foot is an important supporting element of the body. The deformity that may arise in the area of the toes is hallux valgus. It consists in the lateral deviation of the toe and the medial displacement of the first metatarsal bone. It is a medical problem and affects the aesthetics and symmetry of the feet.

The aim of the study was to present how selected sports disciplines affect the morphological structure of the feet, with emphasis on the formation of hallux valgus.

Regular physical activity strengthens the muscles and ligaments of the foot. Most sports do not lead to the formation of hallux valgus, also they can slow down the process of its formation. More frequent occurrence of hallux valgus among female dancers may be due to the wearing of high heels. Foot defects may also appear in people who, as a result of practicing sports, suffer injuries in the distal parts of the lower limb and in those with an increased Body Mass Index.
\end{abstract}

Keywords: hallux valgus, sport, physical activity, deformity

\section{STRESZCZENIE}

Stopa jest ważnym elementem podporowym organizmu. Deformacją jaka może powstać w obrębie palców jest paluch koślawy. Zniekształcenie to polega na bocznym odchyleniu palucha oraz przyśrodkowym przesunięciu pierwszej kości śródstopia. Stanowi problem medyczny oraz wpływa na estetykę i symetrię stóp.

Celem pracy było przedstawienie, jak wybrane dyscypliny sportowe wpływają na budowę morfologiczną stóp, ze szczególnym uwzględnieniem powstawania palucha koślawego.

Regularna aktywność fizyczna wpływa na wzmocnienie elementów mięśniowych oraz więzadeł w obrębie stopy. Większość dyscyplin sportowych nie prowadzi do powstawania palucha koślawego, co więcej może spowolnić proces jego powstawania. Częste występowanie palucha koślawego wśród tancerek może być spowodowane noszeniem wysokich obcasów. Wady stóp mogą pojawiać się również u osób, które w wyniku uprawiania sportu doznały urazu w obrębie dystalnych części kończyny dolnej oraz tych z podwyższonym wskaźniku masy ciała.

Słowa kluczowe: paluch koślawy, sport, aktywność fizyczna, deformacja

\section{INTRODUCTION}

Hallux valgus is a progressive deformity of the foot, which more commonly occurs in women. This pathological condition is characterized as a lateral deviation of the great toe and a medial shift of the first metatarsal bone with a typical bulge at this area. This deformation causes pain, makes it difficult to walk, and reduces the quality of life. In addition to medical complications, this defect also creates cosmetic and aesthetic problems [1].

Hallux valgus can begin to develop in adolescence. The defect may affect both feet and vary in severity. Quite often 
this deformity is hereditary. It rarely occurs alone, most often occurs with the lowering of the transverse arch of the foot. The most frequently indicated factors increasing the risk of hallux valgus are lowering the medial longitudinal arch and the transverse arch of the foot. The presence of inherited muscular-ligamentous laxity may also contribute to development of hallux valgus. Other factors that predispose the occurrence of the above defect are: incorrectly selected shoes, gender, rheumatic diseases, but also being overweight, a standing lifestyle and past injuries [2].

Successful treatment of hallux valgus comes down to surgical treatment. This deformation can be successfully corrected only until skeletal growth stops. After this time, treatment is reduced to relieving symptoms, including pharmacotherapy. An effective method of relieving pain are well-chosen insoles and a change to shoes with the soft uppers. Unfortunately, the anatomical correction of the defect, after the end of growth, can only be performed by surgery [3].

\section{AIM}

The aim of the study was to present how selected sports disciplines affect the morphological structure of the feet, with particular emphasis on the formation of hallux valgus.

\section{SPORT AND HALLUX VALGUS}

The above knowledge leads to the question of how physical activity affects the morphological elements of the foot? Does it predispose transverse flatfoot and aggravation of hallux valgus?

Practicing most sports exposes lower limbs to constant changes of load. The body's response to repetitive effort increases over time. This has a positive effect in most sports.

During training sessions, the feet are exposed to receive constant stimuli. This mainly affects the strengthening of the muscular and ligamentous elements and increase the efficiency of the feet, so in the future they will be able to withstand more training loads without adverse changes in the foot architecture [4]. Regular physical activity also affects the Body Mass Index BMI. Usually, athletic people have a slender figure, which predisposes them to have the correct foot architecture [5].

The impact of physical activity on the condition of the feet is related to several factors. Sport is a very broad subject. The important elements when doing sports are the ground on which you can move and the shoes that are used when practicing a specific discipline.

These features are an important element that should be taken into consideration in order to avoid the formation of the hallux valgus defect. Running is related to other sports. Footwear and a stable surface used in those sports (e.g. football, athletics, handball) mean that the arches of the foot of people who train people do not change compared to people who do not practice sports. The pressure forces affecting on the foot are evenly distributed and properly absorbed. Because of the individual selection of the appropriate equipment, not only can the foot be safe, but also the economy of the running step improves [5-7].

Team sports require a lot of movement dynamics and do not lead to hallux valgus. They strengthen the muscles in the ankle joint and in the foot area [8, 9]. The only disadvantage of such disciplines as basketball, volleyball or football are injuries that may affect the stability of the joints of the lower limb.

Lack of footwear and frequent body injuries are characteristic for combat sports. There were studies that showed that people who train taekwon-do have a greater tendency to the appearance of flat feet at a young age, which in the future will accelerate the appearance of hallux valgus [10]. However, in the case of judo, it turned out that the competitor's body weight was an important factor that influenced the changes in the foot structure [11].

Another sport in which the environment is specific is swimming. Many swimmers have relatively large feet (compared to non-swimmers of similar height), but the occurrence of hallux valgus is not higher among swimmers. Moreover, exercises in the water may contribute to changes in the distribution of the foot load, and consequently reduce the occurrence of flat feet and delay the appearance of hallux valgus in people who are predisposed to it. It is worth noting that swimming affects the appearance of the sole of the foot better than the corrective insole [12].

It is not true that all sports are safe and do not contribute to the development of the hallux valgus posture defect. Very often this deformation appears among standard or Latin dance dancers. Most likely, it is caused by sports shoes, as well as injuries that occur more often the older the dancer is [13]. Where the high heel of the shoe is used, both during training and competition, it can be assumed that the hallux valgus defect will appear more often. In the case of disco dance dancers, foot defects do not appear more often than in non-training people [14].

Other physical activities, in which the lower limbs are not actively loaded, most likely do not contribute to the formation of hallux valgus, e.g. canoeing, chess, sports shooting or car rallies.

If surgery is required, it is worth returning to regular physical activity after surgery. Swimming, walking or cycling can have a very positive effect on the re-habituation of the foot structures to exercise. About $80 \%$ of people are able to regain physical fitness or increase it due to the reduction of pain [15].

\section{SUMMARY}

Most sports can slow down the process of the formation of hallux valgus. Regular physical activity strengthens the muscles and ligaments of the foot and have a positive effect on 
the appearance of the feet. Foot defects may appear in people who have suffered injuries in the distal parts of the lower limb as a result of practicing sports, in people with an increased BMI and also in people who wear high-heeled shoes.

\section{REFERENCES / LITERATURA}

1. Bajerska M, Ambroż A, Wiecheć M. Paluch Koślawy - Postępowania Fizjoterapeutyczne. Praktyczna fizjoterapia i rehabilitacja. 2015;64:32-39.

2. Piejko L, Nawrat-Szołtysik A, Polak A, Grzybowska-Ganszczyk D. Zastosowanie fizjoterapii w leczeniu paluchów koślawych. Rehabilitacja w Praktyce. 2016;2:44-49.

3. Wülker N, Mittag F. The Treatment of Hallux Valgus. Deutsches Arzteblatt International. 2012;109(49):857-868.

4. Kutzner-Kozińska M. Proces korygowania wad postawy. Warszawa: Wyd AWF; 2001:249-281.

5. Błaszczyk A, Błaszczyk M, Zagórski T. Ocena wysklepienia podłużnego stopy u młodych adeptów taekwon-do ITF. Sport Wyczynowy. 2004;11-12:479-480.

6. Grabara M. Influence of football training on alignment of the lower limbs and shaping of the feet. Human Movement. 2008;9(1):46-50.

7. Fuller JT, Bellenger CR, Thewlis D, et al. The effect of footwear on running performance and running economy in distance runners. Sports Med. 2015;45(3):411-422.
8. Bravo-Aguilar M, Gijón-Noguerón G, Luque-Suarez A, Abian-Vicen J. The Influence of Running on Foot Posture and In-Shoe Plantar Pressures. J Am Podiatr Med Assoc. 2016;106(2):109-115.

9. Lizis P, Puszczałowska-Lizis E. Charakterystyka zmian podeszwowej powierzchni stóp oraz związek kąta Clarke’a z wybranymi cechami budowy ciała koszykarzy I ligi polskiej. Fizjoterapia. 2006;14(1):43-52.

10. Lizis P, Puszczałowska-Lizis E, Ridan T. Budowa morfologiczna stóp dziewcząt i chłopców uprawiających siatkówkę. Young sport science of Ukraine. 2011;3:149-153.

11. Havalnou F, Safoura Sabaghian R, Raghad M, Heydar S. The effect of 12 weeks using of customized insoles and exercise in water (front crawl swimming) on plantar pressure distribution and muscle function of girls with flexible flat foot aged 10-14 years. Journal of research in sport rehabilitation. 2019;6(12):31-43.

12. Rietveld B. Dance Injuries in the Older Dancer Comparsion with Younger Dancers. Journal of Dance Medicine \& Science. 2000;4(1):16-19.

13. Leroch M, Łaszcz J, Malon M, Jarzą S. High-heeled shoes and foot pain. Negative impact on plantar pressure changes. Aesthetic Cosmetology and Medicine. 2020;9(3):347-350.

14.Piątek E, Barczyk-Pawelec K, Demczuk-Włodarczyk E, Hawrylak A. Ocena budowy morfologicznej stóp młodych tancerek disco dance. Fizjoterapia. 2015;23(4):24-32.

15. MacMahon A, Karbassi J, Burket J, et al. Return to Sports and Physical Activities After the Modified Lapidus Procedure for Hallux Valgus in Young Patients. Foot Ankle Int. 2016;37(4):378-385. 